AULADUNA: Jurnal Pendidikan Dasar Islam

Vol. 6 No. 2, Desember 2019, pp. 138-146

p-ISSN: 2407-2451, e-ISSN: 2621-0282

DOI: https://doi.org/10.24252/auladuna.v6i2a4.2019

\title{
PENANAMAN NILAI MORAL DAN KEMANDIRIAN BELAJAR DI MADRASAH IBTIDAIYAH DAARUL AITAM PALEMBANG
}

\section{ENGAGING MORAL VALUE AND INDEPENDENT LEARNING IN MADRASAH IBTIDAIYAH DAARUL AITAM PALEMBANG}

\author{
Tutut Handayani ${ }^{1}$, Mardiah Astuti ${ }^{2}$, Amir Hamzah ${ }^{3}$, Meeya Maulina Ismala ${ }^{4}$ \\ ${ }^{1,2,3}$ Prodi PGMI FITK UIN Raden Fatah Palembang \\ 1,2,3JI. Zaenal Abidin Fikri KM 3.5 Palembang, Sumatera Selatan \\ Email: tutuhandayani uin@radenfatah.ac.id ${ }^{1}$, mardiahastuti uin@ radenfatah.ac.id $^{2}$, \\ $\underline{\text { amirhamzah uin@ } @ \text { radenfatah.ac.id }}{ }^{3}, \underline{\text { meeyamaulinaismala040597@gmail.com }}^{4}$
}

\begin{abstract}
Abstrak
Tujuan dari penelitian ini yaitu untuk mengetahui bagaimana moral siswa di MI Daarul Aitam, mengetahui kemandirian belajar siswa di Madrasah Ibtidaiyah Daarul Aitam Palembang, dan untuk mengetahui strategi penanamaan nilai moral dan kemandirian belajar di Madrasah Ibtidaiyah Daarul Aitam Palembang. Jenis penelitian yang digunakan yakni kualitatif. Sumber data yang digunakan adalah data primer dan sekunder. Alat pengumpulan data yaitu observasi, wawancara, dan dokumentasi. Hasil penelitian ini menunjukan bahwa: (1) kondisi moral siswa di Madrasah Ibtidaiyah Daarul Aitam Palembang sudah terlihat baik, dilihat dari nilai religiusnya, cara bersosial siswa, dan kegiatan pembiasaan yang dilakukan siswa di Madrasah Daarul Aitam, (2) kondisi kemandirian belajar siswa di Madrasah Ibtidaiyah Darul Aitam Palembang, juga dikatakan baik karena dalam kegiatan belajar mereka sangat ulet, kreatif, aktif, dan mandiri terutama dalam kegiatan belajar di kelas seperti kegiatan kelompok serta sangat aktif mengikuti kegiatan di luar kelas seperti kegiatan ekstrakurikuler, dan (3) strategi yang digunakan keteladanan atau contoh, kegiatan spontan, teguran, pengondisian lingkungan, dan kegiatan rutin.
\end{abstract}

Kata Kunci: Moral, Kemandirian Belajar, Strategi

\section{Abstract}

The purpose of this research were to determine the students' moral value, independent learning in Madrasah Ibtidaiyah (MI) Daarul Aitam Palembang, and to know the strategies in engaging moral value and independent learning in MI Daarul Aitam. The method used was qualitative research. Data sources were primary and secondary data. The instruments were observation, interviews, and documentation. The results of this study indicated that: (1) the moral condition of students in Madrasah Ibtidaiyah Daarul Aitam Palembang was good from religious side, students' interaction, and regular activities carried out by the students in Madrasah Daarul Aitam, (2) the condition of students' independence in Madrasah Ibtidaiyah Darul Aitam Palembang was also good because of the learning activities of the students were very resilient, creative, active, and independent, especially in classroom learning activities such as group activities and they were very active to participate outside the classroom such as extracurricular activities, and (3) strategies used were examplary, spontaneous activities, reprimands, environmental conditioning, and routine activities.

Keywords: Moral, Independence Learning, Strategy.

How to Cite: Handayani, T., Astuti, M., Hamzah, A., \& Ismala, M. M. (2019). Penanaman Nilai Moral dan Kemandirian Belajar di Madrasah Ibtidaiyah Daarul Aitam Palembang. AULADUNA: Jurnal Pendidikan Dasar Islam, 6(2), 138-146. 


\section{Pendahuluan}

Pendidikan adalah usaha sadar dan terencana untuk mewujudkan suasana belajar dan proses pembelajaran agar peserta didik secara aktif mengembangkan potensi dirinya untuk memiliki kekuatan spiritual keagamaan, pengendalian diri, kepribadian, kecerdasan akhlak mulia, serta keterampilan yang diperlukan dirinya, masyarakat, bangsa, dan negara (Depdiknas, 2003). Pendidikan juga merupakan sebuah aktifitas yang memiliki maksud atau tujuan tertentu yang diarahkan untuk mengembangkan potensi yang dimiliki manusia baik sebagai manusia ataupun sebagai masyarakat dengan sepenuhnya (Nurkholis, 2013). Pendidikan diupayakan dengan berawal dari manusia apa adanya (aktualisasi) dengan mempertimbangkan berbagai kemungkinan yang apa adanya (potensialitas), dan diarahkan menuju terwujudnya manusia yang seharusnya atau manusia yang dicita-citakan (idealitas).

Tujuan pendidikan adalah manusia yang beriman dan bertaqwa kapada Tuhan YME, berakhlak mulia, sehat, cerdas, berperasaan, berkemauan, mampu berkarya, mampu memenuhi berbagai kebutuhan secara wajar, mampu mngendalikan hawa nafsunya, berkepribadian, bermasyarakat, dan berbudaya. Manusia yang berakhlak mulia dan memiliki moralitas tinggi sangat dituntut untuk dibentuk atau dibangun (Inanna, 2018). Implikasinya, pendidikan harus berfungsi untuk mewujudkan (mengembangkan) berbagai potensi yang ada pada manusia dalam konteks dimensi keberagaman, moralitas, individualitas/personalitas, sosialitas dan keberbudayaan secara menyeluruh dan terintegrasi. Dengan kata lain, pendidikan berfungsi untuk memanusiakan manusia. Betapa pentingnya pendidikan untuk memperoleh ilmu bagi kehidupan dunia dan akhirat, terdapat hadist yang mengatakan:

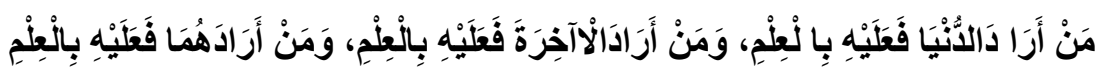

Artinya:

"Barang siapa yang menghendaki kehidupan dunia maka wajib baginya memiliki ilmu, dan barang siapa yang menghendaki kehidupan akhirat, maka wajib baginya memiliki ilmu dan barang siapa menghendaki keduanya maka wajib baginya memiliki ilmu" (HR. Turmudzi).

Hadist ini menjelaskan bahwa dengan ilmu kita bisa bahagia di dunia maupun akhirat. Namun sebenarnya hal ini tergantung dari siapa yang memberi ilmu dan ilmu yang diajarkan. Karena dengan ilmu juga manusia bisa tersesat dan terjerumus kedalam kesengsaraan.

Guru yang baik adalah guru yang senantiasa membimbing siswanya agar lebih baik ke depan, seperti selalu memberikan pelajaran-pelajaran atau masukan yang berguna dan bermanfaat bagi siswa dalam menjalankan kehidupan di era revolusi 4.0. Beberapa sifat guru yang baik adalah pikiran terbuka, humor, kesediaan untuk berbagi sisi pribadinya, merawat siswa, dan spontanitas dalam kelas (Haider \& Jalal, 2018). Guru yang baik itu juga bisa sebagai orang tua dan teman, yang selalu ada pada saat siswa membutuhkannya. Bisa menjadi teman tempat bercerita pada masalah yang sedang dihadapi siswanya.

Menurut Arieya dalam Abidin (2015), guru yang baik itu adalah guru yang memiliki ketulusan dalam memberikan pelayanan (pengabdian) pendidikan, inovatif, dan selalu mengembangkan strategi pembelajaran dan kapasitasnya. Sehingga, memiliki nilai tambah bagi pengembangan dunia pendidikan. Jadi, guru yang baik itu adalah guru yang profesional dalam pengembangan ilmu pengetahuan. 
Berdasarkan hal tersebut perlu adanya peran dari guru sebagai pendidik yang memberikan contoh teladan yang baik, pengetahuan, pemahaman, dan menjadi orang tua siswa selama siswa berada di sekolah serta memberikan pengawasan secara baik dan terorganisir agar dapat memberikan pengaruh yang cukup baik terhadap perkembangan perilaku moral siswa di lingkungan rumah, sekolah, dan masyarakat di sekitarnya untuk menciptakan karakter siswa yang sesuai dengan nilai dan norma yang berlaku di masyarakat. Dengan demikian pendidikan yang baik bukan hanya membentuk siswa memiliki kecerdasan otak saja, melainkan harus membentuk siswa memiliki kecerdasan moral yang baik pula, yang dapat dilakukan dengan memberikan contoh teladan yang baik, penyuluhan, dan bimbingan. Oleh karena itu, peran guru sangatlah penting dalam melakukan tugas yang sangat mulia ini agar terbentuknya karakter yang baik, dan terbentuknya kemandirian belajar siswa untuk proses siswa dalam menyelesaikan tugas akademiknya.

Karakter merupakan nilai-nilai perilaku manusia yang berhubungan dengan Tuhan Yang Maha Esa, diri sendiri, sesama manusia, lingkungan, dan kebangsaan yang terwujud dalam pikiran, sikap, perasaan, perkataan, dan perbuatan berdasarkan normanorma agama, hukum, tata krama, budaya, dan adat istiadat, agar siswa dapat mengontrol diri dari adanya pengaruh dari luar yang dapat mempengaruhi sikap dan perilaku siswa.

Berdasarkan pengamatan yang dilakukan di Madrasah Ibtidaiyah Daarul Aitam Palembang (Observasi di MI Daarul Aitam) ditemukan bahwa ada siswa Madrasah Ibtidaiyah yang mengalami penurunan kualitas moral siswa yang termasuk dalam kategori ringan antara lain terdapat siswa yang lalai dalam menaati peraturan seperti terlambat datang ke madrasah dan adanya keluhan dari guru yang menyatakan bahwa siswa sekarang sulit diatur, tidak patuh, dan suka membantah. Hal inilah yang harus diperbaiki dan dibenahi oleh seorang guru, dalam hal ini guru harus memberikan contoh teladan yang baik, memberikan bimbingan yang tepat agar dapat dijadikan filter atau penyaring oleh siswa untuk mengontrol diri dari adanya pengaruh-pengaruh negatif, dan perlunya penanaman kemandirian belajar agar siswa dapat bertangung jawab dalam tugasnya sebagai siswa di madrasah, maka peneliti sudah melihat secara langsung peran guru di Madrasah Ibtidaiyah Daarul Aitam Palembang mengutamakan penanaman nilai akhlak/moral sejak dini mungkin, terutama dari segi ilmu agama.

Penelitian terdahulu yang dilakukan Haryadi \& Ulumuddin (2016) yang mengungkapkan bahwa penekanan moral sangat penting dengan menggunakan media story telling. Muhtadi (2006) juga menjelaskan bahwa pendekatan untuk menanamkan nilai-nilai agama Islam kepada siswa dilakukan melalui proses pendekatan secara bertahap. Menurut Ruslan, Ely, \& Aini (2016), penanaman nilai-nilai moral pada siswa di SD Negeri Lampeuneurut adalah sebahagian besar sudah baik karena guru sudah menanamkan nilai-nilai moral kepada siswa walaupun ada beberapa guru yang belum sepenuhnya mengetahui nilai-nilai yang harus ditanamkan.

\section{Metode Penelitian}

Penelitian ini menggunakan jenis penelitian lapangan (field research) dengan menggunakan format deskriptif. Pendekatan penelitian yang digunakan adalah pendekatan deskriptif kualitatif, yaitu prosedur penelitian yang menghasilkan data deskriptif berupa kata-kata tertulis atau lisan dari orang-orang dan pelaku yang dapat diamati. Lokasi penelitian adalah Madrasah Ibtidaiyah Daarul Aitam Palembang. 
Peneliti mengumpulkan data dengan teknik pengamatan terlibat (participant observation), wawancara mendalam (indept interview), dan dokumentasi. Analisis data menggunakan analisis data dari Miles dan Huberman, yaitu reduksi, display, dan verifikatif.

\section{Hasil dan Pembahasan}

\subsection{Hasil}

\subsubsection{Moral Siswa di MI Daarul Aitam}

Nilai-nilai moralitas dan budi pekerti yang perlu ditanamkan pada jenjang sekolah dasar adalah sebagai berikut.

a. Nilai religiusitas siswa di MI Daarul Aitam diketahui bahwa siswa dapat terbiasa melakukan kegiatan yang sifatnya mendekatkan siswa kepada Allah SWT. Hal tersebut diperoleh melalui pembiasaan dan peraturan yang ditanamkan oleh guru dan sekolah ini, seperti diadakannya Shalat Duha Berjamaah.

b. Nilai sosial siswa di MI Daarul Aitam Palembang diketahui bahwa mereka memiliki rasa empati yang sangat tinggi, dimulai dari sikap yang santun, ramah baik di dalam ataupun di luar pembelajaran, dan sangat menjunjung nilai sosial.

c. Nilai gender siswa di MI Daarul Aitam Palembang diketahui bahwa sekolah atau guru tidak membatasi kemampuan muridnya sesuai dengan minat dan bakatnya, apabila siswa tersebut memiliki kemampuan dan keahlian dalam bidang apapun itu selagi dia mampu guru selalu memberikan kesempatan untuk mereka lakukan, setiap murid memiliki kesempatan yang sama. Di MI Daarul Aitam terdapat beberapa kelas yang memiliki ketua kelas perempuan.

d. Nilai demokrasi siswa di MI Daarul Aitam Palembang diketahui bahwa siswa sangat aktif dimulai dari mengemukakan pendapatnya, bertanya, menerima perbedaan pendapat bahkan menghargai dan menghormati satu sama lain apabila terjadi perbedaan pendapat, nilai demokrasi ini terbentuk karena peran dan kinerja guru yang baik.

e. Nilai kejujuran siswa di MI Daarul Aitam Palembang untuk saat ini moral mereka mengenai nilai jujur terpantau baik, dalam mereka berkomunikasi maupun sikap mereka saat menghadapi ulangan berlangsung hal ini juga terlihat pada saat dikeseharian siswa di sekolah.

f. Nilai kemandirian siswa di MI Daarul Aitam Palembang terihat dalam proses pembelajaran, mereka lebih mandiri dalam artian mereka memperhatikan penjelasan dari guru dengan baik, tetap mengerjakan tugas yang diberikan guru meski kadang guru meninggalkan kelas sebentar. Hal ini menyebabkan proses pembelajaran murid tetap kondusif dan mengerjakan tugas dengan baik. Selain itu, dalam kegiatan belajar mereka lebih suka belajar secara berkelompok. Pada kegiatan berkelompok tersebut, masing-masing anggota memiliki peran dan tanggung jawabnya sehingga nilai mandiri mereka dalam mengerjakan tugas itu terlihat. Mengenai nilai kemandirian dapat disimpulkan bahwa siswa di MI Daarul Aitam ini terbilang mandiri dalam dalam proses belajar di kelas.

g. Nilai tanggung jawab siswa di MI Daarul Aitam Palembang sangat baik. Bertanggung jawab salah satunya kegiatan upacara atau rutinitas setiap setiap hari senin yang wajib dijalankan, melaksanakan tugas, dan kewajiban mereka sebagai petugasnya dengan baik, kemudian kegiatan-kegiatan yang lainya juga dilaksanakan dengan penuh tanggung jawab. 
h. Nilai peduli lingkungan mereka terbilang sangat peduli. Hal ini dikarenakan mereka tidak membuang sampah sembarangan karena itu lingkungan MI Daarul Aitam terlihat sangat bersih.

Mengenai gambaran moral siswa di MI Daarul Aitam Palembang peneliti dapat menyimpulkan bahwa kondisi moral siswa di MI Daarul Aitam Palembang memiliki nilai moral yang baik.

\subsubsection{Kemandirian Belajar Siswa di MI Daarul Aitam}

Adapun kemandirian siswa di MI Daarul Aitam Palembang yaitu:

a. Kecenderungan untuk berpendapat, berperilaku, dan bertindak atas kehendaknya sendiri. Deskripsi observasi ini terlihat pada saat kegiatan belajar yang mana siswa kelas $\mathrm{V}$ dalam proses belajar mereka terlihat antusias dalam mengemukakan pendapat mereka mengenai ciri-ciri orang munafik, mereka memberikan gambaran bahwa orang munafik itu ada yang perkataannya tidak dapat dipercaya, kemudian ada pula yang berpendapat bahwa orang munafik itu dibenci orang lain dan banyak lagi pernyataan-pernyataan siswa yang lain, dalam hal ini tentu mereka berperilaku atau bertindak berdasarkan pemahamannya sendiri. Selain mereka mempunyai keberanian memaparkan pendapatnya di kelas.

b. Memiliki keinginan yang kuat untuk mencapai tujuan. Deskripsi observasi ini terlihat pada saat kegiatan ekstrakurikuler, beberapa siswa laki-laki sempat menceritakan keluh kesahnya mengenai batalnya kegiatan jadwal tambahan futsal pada hari itu, kemudian di lain hari mereka menanyakan kepastian untuk terlaksananya jadwal tambahan futsal mereka kepada guru olahraganya, hal ini antusias mereka yang begitu kuat agar terlaksananya jadwal tersebut. Selain itu, dalam kegiatan kepramukaan siswa sangat senang dalam kegiatan tersebut, mereka tidak ingin melewatkannya. Untuk itu, setiap jadwal pramuka mereka jarang terlihat datang terlambat.

c. Berusaha dengan ulet dan tekun untuk mewujudkan harapan. Hal ini terlihat pada saat mereka mengerjakan tugas yang diberikan gurunya, semua mengerjakan tugas dengan baik. Selain itu dalam kegiatan belajar kelompok seni budaya, saat membuat prakarya melalui barang bekas seperti botol minum, mereka dengan tekun dan uletnya menciptakan karya-karya terbaik mereka dalam hal ini terlihat keyakinannya untuk menghasilkan karya terbaik.

d. Mampu untuk berfikir dan bertindak secara kreatif, penuh inisiatif, dan tidak sekedar meniru. Hal ini juga terlihat pada saat mereka melakukan kegiatan belajar dikelas, saat diskusi berlangsung, dan memecahkan masalah secara kelompok dengan pendapat yang berbeda-beda namun masih dalam satu pembahasan, selain itu dalam proses pembelajaran seni budaya siswa kreatif menuangkan ide-idenya dalam membuat prakarya tersebut.

e. Kecenderungan meningkatkan prestasi belajar. Deskripsi observasi ini terlihat pada saat mereka mengikuti kegiatan belajar di kelas. Siswa memiliki semangat belajar yang tinggi, kreatif dalam menjawab soal, sering mengemukakan pendapat, memiliki rasa ingin tahu yang tinggi, tekun, dan ulet dalam mengikuti pelajaran di kelas. Apabila terdapat perbedaan pendapat di kelas dan kemudian mendapatkan arahan dari guru mereka mendengarkan dengan baik arahan yang disampaikan oleh guru.

f. Mampu menemukan sendiri tentang sesuatu yang harus dilakukan tanpa mengharapkan bimbingan dan pengarahan orang lain. Deskripsi observasi ini terlihat pada saat siswa dalam proses belajar pada mata pelajaran seni budaya yang mana 
mereka dibagi menjadi beberapa kelompok untuk membuat suatu karya. Guru hanya memberikan materi dan bahan apa yang harus mereka buat yaitu bahan dari botol minum bekas. Siswa terlihat antusias dalam melaksanakan tugasnya. Mereka menuangkan ide-ide mereka dalam karya tersebut.

\subsubsection{Strategi Guru dalam Penanaman Nilai Moral dan Kemandirian Belajar di MI Daarul Aitam}

Strategi guru yang peneliti temukan dalam proses pembelajaran dan di luar pembelajaran seperti ekstrakurikuler. Strategi yang dilakukan melalui pembelajaran yang dilaksanakan di dalam kelas dan luar kelas dalam hal menciptakan penanaman nilai moral melalui metode preventif yaitu yang dilakukan untuk mencegah terjadinya pengaruh buruk yang dapat menimbulkan kesulitan bagi siswa, memelihara situasi yang baik, dan menjaga situasi tersebut baik dan terpelihara adalah sebagai berikut.

a. Peran bersosial guru di MI Daarul Aitam yang memberikan contoh langsung kepada murid mengenai cara mereka berpakaian, berperilaku dengan baik, tata cara menegur, berbicara, dan perilaku lainnya yang mereka praktekkan langsung kepada murid, seperti dalam hal menegur siswa, guru menegurnya dengan kata baik dan tegas.

b. Menyelenggarakan kegiatan dalam rangka memperingati hari-hari besar Islam seperti Maulid Nabi Muhammad SAW.

c. Memiliki ikatan yang baik kepada murid dan wali murid.

d. Menanamkan karakter pada anak dimulai dari kelas I hingga kelas VI guru memfokuskan bagaimana mengaplikasikan nilai kebaikan dalam bentuk tindakan atau tingkah laku, sehingga murid yang belum mengetahui bagaimana berperilaku baik dapat dipelajari siswa, perilakunya sesuai dengan kaidah moral disebut dengan berkarakter mulia.

e. Memberikan tugas dan tanggung jawab mengenai petugas upacara di hari senin, agar terbentuknya nilai tanggung jawab siswa di MI Daarul Aitam Palembang.

f. Mewajibkan siswa melakukan upacara atau kegiatan rutinitasnya dan sebelum dilaksanakannya upacara guru wali kelas masing-masing membiasaan melakukan pemeriksaan rambut, kuku, dan perlengkapan atribut siswa. Ketika terdapat siswa yang tidak memakai atribut yang lengkap, maka wali kelas tersebut memberikan teguran kepada anak tersebut melalui pengumuman agar anak tidak terulang kembali. Hal ini terlihat strategi guru dalam penanaman nilai kedisiplinan siswa.

g. Saat melakukan kegiatan observasi di dalam kelas ketika peneliti memasuki kelas tersebut guru menyampaikan kepada muridnya mengenai menghormati orang yang lebih tua darinya, bertutur kata yang sopan, dan santun dalam bersikap. Hal ini menunjukkan bahwa guru telah menanamkan nilai moral atau akhlak terhadap orang lain.

h. Memberikan kegiatan rutinitas setiap pagi yaitu melakukan Shalat Duha, yang mana setiap harinya siswa bergantian dengan cara roling untuk melaksanakan kegiatan tersebut, rutinitas ini dikhususkan untuk kelas IV-VI agar terbentuknya nilai religius siswa.

i. Mengadakan berbagai kegiatan ekstrakurikuler diantaranya yaitu pramuka, imtaq, keputrian, keputraan, futsal, UKS, Majelis, seni budaya, dan tahfiz.

j. Menetapkan peraturan-peraturan yang ada di sekolah, seperti menjaga kebersihan lingkungan dengan mematuhi jadwal-jadwal piket dan menjaga perlengkapan yang ada di sekolah. 
k. Guru membiasakan untuk memberikan tugas setelah menjelaskan materi pelajarannya kemudian memberikan pekerjaan rumah (PR).

Dalam hal ini terdapat beberapa dokumentasi terkait strategi penanaman nilai moral dan kemandirian belajar siswa di MI Daarul Aitam Palembang yang diterapkan di Madrasah.

\subsection{Pembahasan}

\subsubsection{Moral Siswa di MI Daarul Aitam Palembang}

Menurut Suparno, Rohandi, Sukadi, \& Kartono (2002), nilai-nilai moralitas dan budi pekerti yang perlu ditanamkan pada jenjang sekolah dasar adalah: (1) nilai religius, (2) nilai sosialitas, (3) nilai gender, (4) nilai keadilan, (5) nilai demokrasi, (6) nilai kejujuran, (7) nilai kemandirian, (8) nilai daya juang, (9) nilai tanggung jawab, dan (10) nilai penghargaan terhadap lingkungan. Ibung (2009) juga menambahkan nilai dari dalam diri, kebersamaan, dan pendukung.

Dalam pelaksanaan nilai religius siswa sebagai gambaran moral siswa di MI Daarul Aitam terlihat dalam proses pembelajaran mereka melakukan kegiatan do'a bersama terlebih dahulu dan membaca surah-surah pendek yang telah ditentukan sesuai dengan ketentuan kelas mereka serta membaca ayat kursi dan do'a belajar itu dilakukan setiap pagi sebelum memulai pelajaran mereka. Selain itu, mereka melakukan pembiasaan seperti shalat duha dan selalu memperingati hari besar Islam hal ini dilakukan agar siswa memiliki nilai religius dalam kehidupan

Dalam pelaksanaan nilai lainya seperti demokrasi, sosial pada siswa mengenai dalam buku Suparno, Rohandi, Sukadi, \& Kartono (2002) sebagai gambaran moral siswa di MI Daarul Aitam terlihat dalam cara mereka bersosialisasi baik dengan guru maupun teman, cara mereka bersikap kepada orang yang lebih dewasa, dan kepada teman sebaya menghormati satu sama lain. Sifat terbuka dalam menyampaikan pendapat dan menghargai perbedaan pendapat serta menerima baik pendapat orang lain.

\subsubsection{Kemandirian Belajar Siswa di MI Daarul Aitam}

Menurut teori Sudirman dalam Achmad (2008), ciri-ciri kemandirian belajar siswa terlihat pada saat proses pembelajaran siswa dan di luar pembelajaran siswa seperti kegiatan ekstrakurikuler. Dalam proses pembelajaran siswa sangat aktif mengikuti pembelajaran, ulet dan tekun dalam mengerjakan tugas dari guru, aktif bertanya dan berpendapat secara spontan apabila guru menjelaskan, memiliki keinginan yang kuat dalam belajar baik dalam kelas maupun di luar kelas seperti kegiatan ekstrakurikuler, kreatif dan aktif dalam mengerjakan tugas-tugas sekolah seperti membuat prakarya, senang melakukan kegiatan belajar secara berkelompok, dan gemar mengikuti kegiatan-kegiatan lain, seperti ekstrakurikuler yaitu pramuka, MTQ, keputraan, keputrian, dan mengikuti kegiatan-kegiatan lomba. Dari hasil observasi dan juga wawancara dapat diketahui bahwasanya proses penanaman kemandirian belajar pada siswa di MI Daarul Aitam sudah mengimplementasikan teori Suparman.

\subsubsection{Strategi Guru dalam Penanaman Nilai Moral dan Kemandirian Belajar Siswa di MI Daarul Aitam}

Berdasarkan hasil observasi dan wawancara, dapat diketahui bahwa strategi guru dalam proses penanaman kemandirian belajar pada siswa di Madrasah Ibtidaiyah Daarul Aitam, guru telah menerapkan strategi Contextual Teaching Learning (CTL). Pembelajaran dengan menggunakan pendekatan Contextual Teaching Learning (CTL) 
merupakan pembelajaran yang menekankan pada keterkaitan antara materi pembelajaran dengan dunia kehidupan peserta didik secara nyata (Sunhaji, 2014). Strategi pembelajaran inquiry discovery learning merupakan srtategi belajar mengajar yang menekankan pada siswa untuk belajar mencari dan menemukan sendiri (Jumiati \& Andi, 2018). Strategi pembelajaran ekspositori adalah strategi pembelajaran menekankan kepada proses penyampaian materi secara verbal dari seorang guru kepada sekelompok siswa dengan maksud agar siswa dapat menguasai materi pelajaran secara optimal (Safriadi, 2017). Dalam proses pelaksanaannya segi keteladanan atau contoh, guru di Madrasah Ibtidaiyah Daarul Aitam Palembang mengetahui bahwa mereka merupakan pusat perhatian peserta didik, dalam hal ini guru membiasakan berpakaian rapi, kemudian dari sikap dan tindakan mereka memberikan cerminan suri tauladan. Sedangkan, di dalam kegiatan spontan guru mengajarkan siswa tanpa dibatasi oleh tempat, waktu, dan ruang, yaitu membiaskan bersikap sopan santun, dan bersikap terpuji lainya, seperti menghargai pendapat orang lain. Pada proses pembelajaran di kelas, terdapat siswa yang melakukan kesalahan, guru segera mengarahkan siswa agar tidak melakukan kesalahan kembali, kemudian guru mengingatkan siswa agar merapikan kelas terlebih dahulu sebelum memulai pelajaran. Metode guru menanamkan sifat pembiasaan pada anak yang dilakukan terus menerus di sekolah yaitu membaca do'a sebelum memulai aktivitas, tadarus, dan Shalat Duha. Metode yang diterapkan ini dapat membentuk siswa menjadi lebih mandiri dalam kemandirian belajarnya.

\section{Simpulan}

Moral siswa yang ada di Madrasah Ibtidaiyah Daarul Aitam Palembang baik, karena nilai-nilai moral yang ditanamkan sesuai dengan moralitas dan budi pekerti. Nilai yang sudah diterapkan yaitu nilai religiusitas, nilai sosial, nilai gender, nilai keadilan, nilai kejujuran, nilai kemandirian, nilai tanggung jawab, dan nilai peduli terhadap lingkungan alam. Kemandirian belajar siswa dikatakan baik, karena dalam proses kegiatan belajar di kelas, maupun di luar kelas (ekstrakurikuler) siswa aktif, berani berpendapat, memiliki minat belajar yang tinggi, ulet dan tekun dalam proses belajar, memiliki keterampilan berfikir, bertindak, dan kreatif, serta memiliki kemandirian dalam belajar.

Adapun strategi guru dalam penanaman nilai moral dan kemandirian belajar siswa di Madrasah Ibtidaiyah Daarul Aitam Palembang dilakukan dalam proses pembelajaran dan ekstrakurikuler, melalui metode kedisiplinan, kegiatan rutin, nilai religius, keteladanan, teguran, peduli lingkungan, dan lainnya. Hal ini yang menjadi pengaruh terbesar dalam terbentuknya nilai moral dan kemandirian belajar siswa di Madrasah Ibtidaiyah Daarul Aitam Palembang.

\section{Daftar Pustaka}

Abidin, R. F. (2015). Peran Guru Pendidikan Kewarganegaraan dalam Mengembangkan Kecerdasan Moral Siswa Kelas VIII di SMP Negeri 18 Bandar Lampung (Universitas Lampung). Retrieved from http://digilib.unila.ac.id/7582/

Achmad, I. F. (2008). Pengaruh Kemandirian Belajar dan Disiplin Belajar terhadap Peserta Belajar Siklus Akuntansi Siswa Kelas X SMK Negeri 7 Yogyakarta 
Tahun Ajaran 2007/2008. Universitas Negeri Yogyakarta.

Depdiknas. (2003). Undang-Undang RI Nomor 20 Tahun 2003 tentang Sistem Pendidikan Nasional. Jakarta: Depdiknas.

Haider, A., \& Jalal, S. (2018). Good Teacher and Teaching through the Lens of Students. International Journal of Research, 5(7), 1395-1409. Retrieved from https://www.researchgate.net/publication/324106485_Good_Teachers_and_Teac hing_through_the_lens_of_students

Haryadi, T., \& Ulumuddin, D. I. I. (2016). Penanaman Nilai dan Moral pada Anak Sekolah Dasar dengan Pendekatan Storytelling melalui Media Komunikasi Visual. Andharupa Jurnal Desain Komunikasi Visual dan Multimedia, 2(1), 5672. Retrieved from http://publikasi.dinus.ac.id/index.php/andharupa/article/view $/ 1018 / 791$

Ibung, D. (2009). Mengembangkan Nilai Moral pada Anak Panduan bagi Orang Tua untuk Menjadi Anak yang Baik. Jakarta: PT Elex Media Kompatindo.

Inanna. (2018). Peran Pendidikan dalam Membangun Karakter Bangsa yang Bermoral. JEKPEND Jurnal Ekonomi dan Pendidikan, 1(1), 27-33. Retrieved from http://ojs.unm.ac.id/JEKPEND/article/download/5057/2888

Jumiati, N., \& Andi, S. (2018). Pengaruh Metode Inqury Discoveri Learning terhadap Hasil Belajar PKn Siswa Kelas IV SDN 139 Kecamatan Duampanua Kabupaten Pinrang. Jurnal Etika Demokrasi Pendidikan Pancasila dan Kewarganegaraan, 3(1), 12-21. Retrieved from http://journal.unismuh.ac.id/index.php/jed/article/ download/1207/1106

Muhtadi, A. (2006). Penanaman Nilai-Nilai Agama Islam dalam Pembentukan Sikap dan Perilaku Siswa Sekolah Dasar Islam Terpadu Luqman Al-Hakim Yogyakarta. Jurnal Penelitian dan Evaluasi Pendidikan, 8(1), 1-15. Retrieved from https://journal.uny.ac.id/index.php/jpep/article/view/2008/1655

Nurkholis. (2013). Pendidikan dalam Upaya Memajukan Teknologi. Jurnal Kependidikan, 1(1), 24-44. Retrieved from http://ejournal.iainpurwokerto.ac.id /index.php/jurnalkependidikan/article/download/530/473/

Ruslan, Ely, R., \& Aini, N. (2016). Penanaman Nilai-Nilai Moral pada Siswa di SD Negeri Lampeuneurut. Jurnal JIM Unsyiah/PGSD, 1(1), 68-77. Retrieved from http://jim.unsyiah.ac.id/pgsd/article/view/431/262

Safriadi. (2017). Prosedur Pelaksanaan Strategi Pembelajaran Ekspositori. Jurnal Mudarisuna Media Kajian Pendidikan Agama, 7(1), 47-65. Retrieved from https://jurnal.ar-raniry.ac.id/index.php/mudarrisuna/article/view/1908/1418

Sunhaji. (2014). Konsep Strategi Contekstual Teaching Learning dalam Pembelajaran. Jurnal Candi, 7(1). Retrieved from http://jurnal.fkip.uns.ac.id/index.php/ sejarah/article/view/4339http://jurnal.fkip.uns.ac.id/index.php/sejarah/article/vie w/4339

Suparno, P., Rohandi, R., Sukadi, G., \& Kartono, S. (2002). Reformasi Pendidikan Sebuah Rekomendasi. Yogyakarta: Kanisius. 